\title{
In exile from ourselves?
}

Tartanry, Scottish popular theatre, Harry Lauder and Tartan Day

\section{Ian Brown}

\section{(2) OpenEdition}

\section{Journals}

Electronic version

URL: http://journals.openedition.org/etudesecossaises/155

DOI: 10.4000/etudesecossaises. 155

ISSN: 1969-6337

\section{Publisher}

UGA Éditions/Université Grenoble Alpes

\section{Printed version}

Date of publication: 31 March 2005

Number of pages: 123-141

ISBN: 2-84310-061-5

ISSN: $1240-1439$

\section{Electronic reference}

Ian Brown, «In exile from ourselves? », Études écossaises [Online], 10 | 2005, Online since 31 March

2005, connection on 07 September 2020. URL : http://journals.openedition.org/etudesecossaises/155

; DOI : https://doi.org/10.4000/etudesecossaises. 155 
lan Brown

\title{
In exile from ourselves?
}

\author{
Tartanry, Scottish popular theatre, \\ Harry Lauder and Tartan Day
}

Within the interactions of any culture, discussion concerning what is «authentic» or «true» is subject to intellectual fashion, social snobbery and political manufacture and profoundly affects responses to cultural expression. Where a «home» culture has a significant diaspora, these discussions may be even more fraught. Questions arise about the nature of «authenticity», the "true» repository of correctness and who has the right to judge what is «true». Often the home or metropolitan culture will see itself, rightly or wrongly, as having the «authentic» tradition, or at any rate the right to adjudicate on what is «authentic» within its own cultural expressions. These in turn are promoted as the lodestone for any assessment of «authenticity» within the diaspora culture. These cultural expressions are, often, of course, developed and presented in theatrical and quasi-theatrical modes, including popular theatre performance and the management of public ceremonial. This article will consider the cultural expression of «Scottishness" through tartanry and popular theatre forms. In doing so, the question of what purposes the use of such terms as «authenticity» or «truth» serve with regard to such cultural expression will be considered. It will be argued that, in fact, such terms or their cognates have sometimes been appropriated in a way that distracts discussion and understanding away from important issues in the dynamics of cultural identity.

As time passes, and traditions emerge, or are manufactured, coteries of interest form, claiming the right to define what is acceptable, correct or right. Whether authorised by others, as with Louis XIV's foundation of the Académie française, or self-appointed as with, for example, the members of the Scottish Renaissance Movement, such coteries arrogate to themselves the right to define and promulgate what is «authentic» or «true». Clearly the degree of authority any 
1. See, for example, Colin MacArthur [sic], «Breaking the Signs: "Scotch Myths" as Cultural Struggle», Cencrastus, ${ }^{\circ} 7$, Winter 1981-1982, p. 21-25; Colin McArthur, «Scotch Reels and After», Douglas and Ouainé Blair, Gillian Skirrow, «Woman, Women and Scotland: "Scotch Reels" and Political Perspectives », Cairns Craig, "Visitors from the Stars: Scottish Film Culture», all grouped under the heading, «Scotland: The Reel Image ", Cencrastus, $\mathrm{n}^{\circ} 11$, New Year, 1983, p. 2-11. 2. "Introduction", McArthur, 1982, p. 2. such coterie is formally assigned or achieves through custom and practice will vary from case to case and time to time. The working of such coteries - and they include critical coteries nevertheless affects the ways in which a culture perceives and values itself. Internally, coteries often establish powerful and even autocratic rules of taste that may mean that the very reading of history is profoundly affected by prevailing perceptions or permitted readings. In turn, these «rules» may affect relations with diaspora members and the perceptions of the diaspora's own view of what is «authentic». This paper considers the perception of certain strands of Scottish popular culture and theatre, both historic and current, and seeks to consider larger lessons to be learned from an analysis of the historical context behind such perceptions. In doing so, it will address the ways iconic figures like Harry Lauder have been seen. It will consider whether the time has come to re-evaluate aspects of popular theatre and culture that have in recent years been regarded as «inauthentic» and somehow unworthy. It will finally relate these considerations, drawing on personal observations of the author, to the public ceremonies of Scottish diaspora communities, including such public theatre as the Tartan Day celebrations in the United States of America.

In 1981 Murray and Barbara Grigor curated an exhibition, Scotch Myths presented at St Andrews and Edinburgh. Out of the experience of this exhibition a number of articles ${ }^{1}$ and, above all, Colin McArthur's collection of essays, Scotch Reels (1982) was published, critical of tartanry and all its works. McArthur himself observes :

Denied by history [because of the effects of Unionist imperialism and precocious industrialisation] a place in the cadres of the forces of progress [...] and shorn of the role of shaping - through particular works of art and polemic - the ideologies appropriate to a burgeoning nation, Scottish artists and intellectuals, where they did not leave Scotland and function solely within the discourses of other cultures, produced works in or about Scotland which were deformed and «pathological». Undoubtedly the most dominating on the "pathological» discourses are Tartanry and Kailyard, traditionally a source of dismay and aversion to Scottish intellectuals, but regrettably not the object of any sustained analysis ${ }^{2}$.

Cairns Craig observes of these so-called «pathological» discourses : 
Tartanry and Kailyard, seemingly so opposite in their [noble Celtic and mundane, parodic lowland] ethos, are the joint creations of an imagination which, in recoil from the apparently featureless integration of Scottish life into an industrial culture whose power and whose identity lies outside Scottish control, acknowledges its own inability to lay hold of contemporary reality by projecting itself upon images of a society equally impotent before the forces of history.

This turning of the back on the actuality of modern Scottish life is emblematically conveyed in the figure of Harry Lauder - Kailyard consciousness in tartan exterior - who evacuates from his stage persona, indeed from his whole identity, the world of the Lanarkshire miners from which he began ${ }^{3}$.

Murray Grigor, in the same collection, remarks of the development of tartanry:

Banned for almost a generation after the' 45, the wearing of the tartan was wholly legitimised and appropriated when George IV appeared kilted in Edinburgh in 1822. Tartan gave way to Tartanry in a massive mythicising surge with MacIan's prints [of romanticised Highlanders] [...] offering historically inaccurate but ideologically fulfilling models for Victorian Scots bent on constructing their own personal Scottish past ${ }^{4}$.

John Caughie continues the attack:

It is precisely the regressiveness of the frozen discourses of Tartanry and Kailyard that [...] can be drawn upon to give the «flavour of Scotland», a petrified culture with a misty, mythic, and above all, static past ${ }^{5}$.

The overarching theme of both exhibition and articles was to excoriate tartanry, the sentimentalisation of Scottish culture through the manufacture of what was presented as a false representation of Scottish identity, and what was represented as its interlinked partner in cultural identity theft, Kailyard.

Yet, it must be clear that identity is never simply any one Against History: Tartanry and Kailyard in 19th-Century Scottish Literature», McArthur, p. 13.

4. Murray Grigor, «From Scott-land to Disneyland», McArthur, 1982, Scotch Reels, p. 17. 5. John Caughie, «Scottish Television: What Would It Look Like?» (McArthur, p.116). thing. There can be no doubt, from the very fact that the exhibition was possible, that for many decades what was called by its critics «Tartanry» had been an important definer of aspects of Scottish identity, both at home and among diaspora members. It was not then, and never had been, the case that all Scottish identity was bound up in tartanry. Tartanry was and, despite the assaults by its critics, still is one of the elements that go to make up perceptions of Scottishness. Of course, in their assaults on tartanry such critics were part of a tradition in 
Scottish cultural politics that goes back at least as far as Hugh MacDiarmid's famous attacks on Harry Lauder in poetry and prose:

It's no'sae easy as it's payin'

To be a fule like Lauder

$[\ldots]$

The problems o'the Scottish soul

Are nocht to Harry Lauder ${ }^{6}$.

MacDiarmid praises his own «singleness of mind» to which he claims «a sense of humour» is enemy and boasts, in this context, of

my furious attacks on Sir Harry Lauder, Will Fyffe, Tommy Morgan, and the other Scotch comedians - and the «chortling wut", like the offscourings of the patter of these clowns which is so large a constituent of Scottish life on every social level. (MacDiarmid, 1943, p. 80)

Earlier, MacDiarmid had claimed to have «never met a single intelligent Scot, who would be seen at a Lauder performance $^{7} »$. The vehemence of his stance and his desire to separate Lauder from «the Scottish people» leads MacDiarmid to claim, in the same article, that the reason Lauder's perfor mances in Scotland played to full houses was because «There are plenty of non-Scottish people in Scotland to supply him with the necessary audiences» (MacDiarmid, 1997, p. 114). Regrettably, we appear not to have data regarding audience composition with which to prove or disprove such an assertion. It must be said, however, that the idea of Lauder's filling the largest theatres in Scotland on a regular basis on the basis of the nonScots in the population seems a little far-fetched. Indeed, such an assertion might seem a little like a desperate - and unsustainable - attempt to maintain MacDiarmid's argument that Lauder is not really «truly» Scottish. (Or it may even be that he

6. «To Circumjack Cencrastus»

(McDiarmid, 1978, p. 248).

7. Hugh MacDiarmid [identified as « Special Correspondent»], "Scottish People and" Scotch Comedians", The Stewartry Observer, 23 August 1928 (MacDiarmid, 1997, p. 114). considers Scots who attend Lauder's performances as not «really» Scots, that is, redefining these Scots as «non-Scots ». If it were this, then the spuriousness of the self-serving legerdemain would seem entirely clear - and threadbare). MacDiarmid's attempt to separate Lauder from his full houses of Scots reminds us of Craig Beveridge and Ronald Turnbull's description of such a stance as «inferiorism». Discussing the application of Frantz Fanon's term «inferiorisation» in describing the cultural dimensions of colonialism, they talk of the 
role of the «intelligentsia», including, presumably, critics, as follows :

Drawn to an external culture which is hostile or condescending towards Scotland, the intelligentsia display a marked alienation from their compatriots. A pointed example is to be found in the way intellectuals write about the working class ${ }^{8}$.

And, it might be added, working class entertainment, especially when it might be seen as having a right-wing bias and even when they have working class roots themselves. It is sometime hard in considering the views underlying these attacks not to discern something of what Paul Maloney calls:

the demonising tendencies of crusaders against music halls of the 1870 s, one of whom had written that «one's blood runs cold to think that there are men and women in our midst who can pander to the vile tastes of those who frequent such places ${ }^{9}$ ».

Such underlying views have recently come into serious question. David McCrone, for example, argues :

Indeed, if our argument is correct that, far from being dependent on or subservient to England since 1707, Scotland has operated with a considerable degree of civil autonomy, then it follows that its cultural formations and expressions reflected that. Those who point out that nineteenth-century Kailyard was not the simple expression of a deformed culture, but one manifestation of a developing international literature, have their analogue in those who attribute the popularity of tartanry to the development of music hall and vaudeville in the twentieth century. In practice, the ant-tartanry, anti-Kailyard obsessions of writers on the 1970s have not only been questioned as historically inaccurate, but many of the symbols themselves have been mobilised as icons of opposition against current political arrangements. (McCrone, p. 87)

McCrone goes on to summarise his position:

Much of the attack on tartanry and Kailyard has depended on an uncritical assumption that their impact has been comprehensive and homogenous. (McCrone, p. 189)

8. Craig Beveridge and Ronald Turnbull, "Inferiorism», Cencrastus, no. 8, Spring 1982, p. 4. 9. (Maloney, 2003, p. 140), quoting from "A Night in a Glasgow Music Hall», letter, North British Daily Mail, 24 February 1875, p. 4.
On the question of tartanry itself, Murray Pittock has offered acute, sustained and historically deeply researched critiques of the mythology of «Scotch Myths». He observes, for example:

we may do right if we feel uneasy about the degree of demythologisation which has challenged the kitsch of tartanry in the last quarter of a century, $[\ldots]$ such demythologisation is effectively only the creation of a new myth. In Scottish popular history and 
cultural studies, the exposure of so-called «myths» to which our cultural identity has been in thrall has become quite an industry. The exposure of «myths» is held to be of service. I cannot find it so. [...] the destruction of myths is itself a manifestation of the values of a centring «British» history. The attack on tartanry is only a further attack on self, yet another example of those earlier attacks which themselves were responsible for simultaneously limiting and exaggerating the role of tartan in Scottish identity. (Murray, p. 117-118)

Pittock has recently summarised his view on the role of tartan and tartanry as follows :

tartan was not the synthetic production of nationality by WS [Walter Scott], but the badge of «old Scotland», hence the Jacobite armies were uniformed in it in 1688-1746, irrespective of origin. When it was revitalized in $\mathrm{C} 19$, it was not the invention, but the reaccommodation of the national self within a British paradigm which allowed its survival as - well, as theatre eventually music-hall and the degringolade which led us to $1980 \mathrm{~s}$ Hogmanay programming. To excoriate it for being false Scottishness on those grounds is to deny Britishness any formative role in modern Scottish identity. The reappropriation of it (as in the US) I think more mature than the striving for "authenticity", especially when that "authenticity» is, as in the Invention of Tradition accounts of tartan, erroneous \& inadequate ${ }^{10}$.

Dealing with the topic of Scottish popular theatre and particularly Harry Lauder's predecessor W.F. Frame, Alasdair Cameron and Adrienne Scullion reinforce the points being made by McCrone and Pittock when they observe of the image of the Scotch comic:

We want to reconsider this image, and with that the other images of Scotland, Scottishness, Scotsmen and Scottish women created for and disseminated by the Scottish popular stage, insisting upon the enormous success and appeal of such images for the audience for whom they were created. Further, we want to suggest that the totemic images of the Scotch comic [...] were approved and even celebrated as symbols of a nationality which, under normal circumstances, audiences were never allowed to express. These

10. Murray G. Pittock, personal communication, October 2004

11. Alasdair Cameron and Adrienne Scullion, «W.F. Frame and the Scottish Popular Theatre Tradition" (Cameron \& Scullion, 1996, p. 39). images, be they nostalgic, parochial or romantic, were produced and maintained within the entertainment ecology of Scotland but were given their universal power and currency by their appeal to the Scottish diaspora of North America and the Empire ${ }^{11}$.

It is noteworthy that Cameron and Scullion revise McCrone's dating of tartanry as a music hall phenomenon back from the twentieth to the nineteenth century. 
Certainly, Lauder with his overstated tartan costumes and couthy humour has often been seen as the reductio ad absurdum of a synthetic Scottishness. For this he has been excoriated both in his time and since. Yet Lauder and his predecessor, W. F. Frame, were not only popular in Scotland, but international stars. Lauder himself travelled throughout Britain, Canada, the USA and Australia. What he was engaged in was ideologically controversial; clearly, it was not in any sense unpopular with Scots at home or in the diaspora. Part of the purpose of this article is to argue that the assault on Lauder and his peers, and by extension what is called «tartanry» as a «Scotch Myth», fails to take account of a number of factors both cultural and theatrical that shaped his performances. His function was far more positive than MacDiarmid, for one, understood. In order to understand this function, it is worth considering the position of Scotland within the United Kingdom throughout the nineteenth century.

Cairns Craig has recently argued that there has been a misreading of the relationship of Scotland and England since the Union, one which sees Scotland as somehow subsumed within Britain and «Britain» another term for «England». Craig, however, suggests:

there is an alternative way of viewing these relationships: what nineteenth-century Scotland developed was a Scoto-British constitutional identity whose nationalism consisted in the long-drawnout struggles to maintain the independence of precisely those institutions - church, law and education — which had originally been guaranteed by the Act of Union. The paradox, in other words, is that Scotland's nationalism was already enshrined within the Act of Union, and defence of the Union was the first and immediate resort for those defending the rights of Scottish culture. As Graeme Morton has argued, «unionist nationalism» was the very basis of nineteenth-century Scottish culture, so that «however strange it may seem to twentieth-century nationalists: Scotland wanted more union, not less. Scotland's mid-nineteenth-century nationalists believed their nation had entered the union of 1707 as an equal, and that was how they demanded to be treated ». Indeed, the movement for Scottish Home Rule developed not so much out of resistance to the Union but out of insistence upon it, and upon the fact that the treaty was being breached by the Westminster

12. Cairns Craig, «Constituting Scotland», The Irish Review, $\mathrm{n}^{\circ} 28$, Winter 2001, p. 5. parliament ${ }^{12}$.

Craig's insight is interesting, albeit perhaps rather general, and, like any good theory, provides explanations for observed 
phenomena. In particular it offers another explanation for the absence of separatist nationalism of any great force in Scotland during the nineteenth century. Then, in other European nations nationalism was a strong force, whether for unification in Germany or for separatism in the Austro-Hungarian Empire (culturally, as for example in the foundation of the Croatian National Theatre as long ago as 1832, or politically, as in the 1848 Hungarian Rising). The engagement of Scots in the enterprise of Empire may well provide economic and social reasons to complement and support «unionist nationalism», and incidentally provide the reason for some of the diaspora's existence. The political thrust identified by Craig, however, provides one possible unifying ideology for Scots engaged in Empire. Craig's argument complements Pittock's on the embracing of tartanry as a unifying Scottish symbol from before the time of the Treaty of Union to that of Harry Lauder and beyond. Within the framework of the Union, it was essential to find easily identifiable and specifically Scottish symbols that might mark the continuing identity of the equal partner in the Union that Scotland constituted. Lauder, like his predecessor, W.F. Frame, effectively follows, even if he exaggerates, the use of Highland dress as symbol of «old Scotland».

Lauder's use of tartan, further, had an underlying theatrical dimension that lay in the nature of the music hall in which he made his career. A number of theatre historians have made the point that the music hall in Scotland is a separate institution from that of England with its own development and traditions. Paul Maloney, for example observes that

the music hall that evolved in Scotland has a special place in the nation's theatrical life: highly influenced by the fairground tradition, it was not, as in England, necessarily seen as a cruder appendage to an aesthetically rich legitimate theatre, but rather as something much closer to the mainstream, and to the Scots vernacular stage which constituted many people's experience of theatre-going. (Maloney, p. 8)

Maloney goes on to discuss the fact that music hall in Scotland enshrines popular Scottish people's theatre alongside pantomime - in the wake of the decline in the mid to late nineteenth-century of the National Drama. The latter was, of course, shaped by highly popular adaptations of Scott's novels for the stage that made use of Scots language, theatrical 
conventions and actors. Barbara Bell identifies this form as responding to

a real sense of frustration among many Scots at the perceived cultural and institutional drift towards reducing the status of their nation to "North Britain", which was only partly halted by the work of Burns and Baillie. Dramatisations of the Waverley Novels began to effect a real change. [...] Their comparative respectability, despite their setting in Scotland's recent past, allowed their transfer on to the stage, where they made Scotland's history an acceptable subject for representation. [...] for the first time in many years, Scotland's actual history and character were considered serious subjects for plays and players. [...] the Scots, hungry to reassert their shared cultural identity in a public arena, returned again and again to see their national heroes and heroines portrayed in authentic Scottish settings by Scottish actors with Scottish accents. (Barbara Bell, «The Nineteenth Century»; Findlay, 1998, p. 141)

The Scottish musical hall, then, according to Maloney, continued in some way to portray, in Bell's words, «Scottish settings by Scottish actors with Scottish accents». Indeed, he argues that its influence did not cease in the nineteenth century:

In this context the Scottish music hall can be seen to have been directly in the line of a mainstream Scottish popular theatre tradition that continued through the socialist plays of Joe Corrie and the Fife Miners'Players, who performed their one-act plays to working-class audiences in music halls and variety theatres, to the radical popular theatre of companies such as Wildcat and John McGrath's 7: 84 Theatre Company in the 1970s and 1980s, who claimed its legacy as their own. (Maloney, p. 8-9)

This places Scottish music hall and its performers within a rather subversive genealogy.

The linkage between the performers in the popular National Drama and later popular forms such as the music hall is clear. Bell, referring to Charles Mackay, leading performer for W.H. Murray's Theatre Royal, Edinburgh, famed for his performances in Scott, pre-eminently as Baillie Nicol Jarvie, and the byword of authenticity as «the real Mackay», notes:

Very early on the National Drama had also spawned the phenomenon of characters who stepped out of their play settings to perform songs or monologues as individual acts, the forerunners of the well-loved characters created by Scottish variety artists. Mackay, for example, toured an «Interlude» ostensibly 
13. Bill Findlay, «Scots Language and Popular Entertainment in Victorian Scotland: the Case of James Houston» (Cameron and Scullion, p. 16).

14. James Houston, Autobiography of Mr James Houston, Scotch Comedian (Glasgow and

Edinburgh: Menzies and Love, 1889) p. 69, quoted by Findlay, p. 16 . from St Ronan's Well, which was a thinly veiled opportunity for him to sing "There cam a young man to my Daddy's door» in character as Meg Dods. (Bell, Findlay p. 153)

It is difficult to know in light of current research whether Mackay was following an existing tradition of working across boundaries between what would now be seen as text-based and variety theatre or establishing such boundary crossing as an acting mode for the first time. It is, nevertheless, certain that since his time such boundary transgression by leading actors has been a specific dimension of Scottish theatre practice. Bill Findlay notes, for example, that James Houston, having established himself as a Scotch comic, "was invited to take the part of Bailie Nicol Jarvie in Rob Roy at the Theatre Royal, Glasgow, in 1875 . He was then forty-seven years old ${ }^{13}$ ». At that age, Houston was already established as a Scotch comic and so Findlay's observation that he now established himself as a «natural comic actor» reminds us of the continuity of the line from Mackay himself. Indeed, Houston makes the point that he had now, in his own words, «secured the mantle of his noted predecessors ${ }^{14}$ » who included Mackay himself. This line in Scottish performativity continues even into modern times. Such current figures as Una McLean, Andy Grey, Forbes Masson and Elaine C. Smith, for example, work on the Scottish stage in both straight drama and pantomime.

Alasdair Cameron and Adrienne Scullion place the genesis of Scottish music hall in the Saltmarket area of Glasgow,

one of the most deprived areas of the city and home to first the waves of dispossessed Highlanders who came to Glasgow in the wake of the Clearances and subsequently to the Irish immigrants who came in the wake of famine and in pursuit of work. In the pubs and shebeens of this community drink gave way to ceilidhs and informal sing-songs and music making. (Cameron and Scullion, p. 40)

Scullion further suggests that, whatever the linked, but separate, English experience may have been, in Scotland «a particular and significant influence in the evolution towards music halls per se came from this ceilidh tradition, which these communities brought with them to industrialising Glasgow». She goes on:

I, therefore, see the ceilidh as a key factor in the development of what is a uniquely independent Scottish popular theatre. It may 
indeed by the case that music hall in Glasgow developed slightly ahead of music hall in London (which tends to be dated in the 1850s), and although this needs more careful sourcing, the influence of the immigrant Highlanders moving to Glasgow, combined with the particular scale and reputation of the Glasgow Fair points to an independent (and significantly early) evolution of this type of entertainment. (Cameron and Scullion, p. 40, fn. 3)

It is widely accepted that «free and easies», which were «informally organised concerts put on in the backrooms of public houses» and effectively a form of ceilidh, were immediate antecedents of the music hall (Maloney, p. 27). Scullion's theory, then, has much to commend it in the particular cultural context of early and mid nineteenth-century Glasgow.

Adrienne Scullion is not alone in detecting and identifying specific Scottish cultural elements in Scottish music hall and «Scottish Variety», its later development. Femi Folorunso, for example, places the latter firmly in a popular tradition going back four centuries:

from its introduction until the late 1940s, it was the most popular and richest form of entertainment in Scotland [...] and [... occupied the middle space in a direct line from the seventeenthcentury popular entertainment to contemporary drama in Scotland ${ }^{+5}$.

Indeed, he dates the interaction of popular and text-based theatre to a very early period:

We now know, for instance, that a pattern of utilitarian drama was established in Scotland before the Reformation. This pattern achieved its highest standards in Sir David Lindsay's Ane Satire of the Thrie Estaitis. A close scrutiny of the language and techniques of this play suggests very much the kind of imposition [...] of literary order on popular elements in order to make some urgent, serious political statements. (Stevenson \& Wallace, p. 182)

Folorunso also discusses the origin of the specific popular theatre form of the Scottish pantomime. He argues that this perpetuates elements of the wonderful and supernatural that may initially have been inspired by Celtic folklore, or descended partly from seventeenth-century circuses and mountebank shows. (Stevenson \& Wallace, p. 183). His work, then, concurs

15. Femi Folorunso, «Scottish Drama and the Popular Tradition» (Stevenson \& Wallace, p. 177). with that of Scullion, Cameron and Maloney in seeing Scottish popular theatre in its various forms as embodying not just an assertion of Scottish difference, but doing so on the basis of its development out of, and incorporation of, older Scottish forms. 
Such difference continues to the present day. In discussing the development of 7:84 (Scotland) Theatre Company, Maria DiCenzo observes :

One of the advantages of the Scottish [7:84] company was that it could merge class politics with specific regional/national problems for an audience more than ready to listen to and support them. Scottish issues provided a focus for the subject matter of the plays and popular Scottish entertainment (both rural and urban) provided the language through which to reach audiences. (DiCenzo, p. 85)

She goes on to note:

In theatrical terms, what Scotland could claim to be its own was a tradition of popular forms such as music hall and panto - live forms of entertainment in which music and comedy figure prominently. (DiCenzo, p. 87)

An additional and central element in this tradition is, of course, the Scots language. While there has not been extensive study of its use in itself on the Scottish stage, there is clear evidence that the use of Scots forms a conscious part of the tradition of contemporary variety performers (and indeed playwrights). Doctoral research currently being completed by Margaret Munro makes entirely clear that this is in part in order to assert community of culture with audiences ${ }^{16}$. Bill Findlay, following work by Alasdair Cameron, talks of the use of Scots language in the nineteenth century as addressing «a nationalist assertiveness in Scottish audiences» preference for Scottish material on the Victorian stage'bound up with the creation of a new national identity:

the demand for Scots language material can, at least partly, be seen as reflecting an assertion of community. Although it is, of course, important not to forget the sheer enjoyment aspect, in terms both of the shared pleasure of linguistic and cultural recognition, and the escapism afforded by comedy, in a complementary way I think the demand for Scots language material can also be seen as contributing to the creation of a

16. Margaret Munro, Language and Cultural Identities in the Scots Comic Tradition, $\mathrm{PhD}$ thesis, Queen Margaret University College, Edinburgh, currently submitted for examination. national identity through Scottish types. (Findlay, p. 34)

One of the attractions of asserting cultural community is the potential for establishing a cultural identity of using language that may be difficult for others to understand. Ian Brown and Katja Lenz have drawn attention to just such a device in the use of Scots in the BBC television comedy series 
The High Life, written and performed in by the actors Forbes Masson and Alan Cummings and broadcast in 1995. Brown and Lenz talk of the writer/ performers' «linguistic awareness» and

their concern to exploit the creative potential of the interaction of English and Scots in dialogue, and their use of Scots words and forms, particularly those incomprehensible to English-only speakers, to achieve a subversive comic effect ${ }^{17}$.

The subversive effect undermines the authority of a monolingual English-speaking hegemony that cannot understand the implications of what is addressed to its members in Scots. At times, this subversion extends beyond the drama into the authors'relationship to the BBC itself. The word «fud» was used freely on several occasions in this series. This, of course, is the Scots word for the female genitalia and to Scots speakers can cause offence as much as its English equivalent, which is so proscribed that it is often referred to as the «c-word». It is inconceivable that the English word would be used in an early evening programme like The High Life, or perhaps at all, on BBC television, while Masson and Cummings were able to infiltrate this word into their scripts at apparent will. Presumably this was possible because monolingual English editors did not understand the effect of what was being said in terms of producers'guidelines about what was permissible before the nine o'clock watershed. This is a particular case, of course, but illustrates the power of Scots still to act as a cultural identifier. In this performance context, Scots language use can often seem to have the subversive role of camp language. «Camp»

engages and politicizes by providing alternative, even oblique sensibilities which broaden and more often than not challenge, traditional ways of perceiving situations and objects. It creates new ways of seeing and relating to authority, [...] Camp is always undermining authority, whether this be aesthetic, literary or artistic «rules» or political or social power. (Lucas, p. 115)

Particularly in popular culture, this function of undermining authority is one that Scots language use often fulfils.

Given all of this historic and contextual material, it seems

17. Ian Brown and Katja Lenz, " OO
Dearie Me!": dramatic rhetoric and linguistic subversion in the Scottish situation comedy, The High Life » (Schneider, p. 112). wise to re-evaluate the role of figures like Harry Lauder as significant and positive emblems of aspects of Scottish culture within a potentially hegemonic and metropolitanised politicocultural context. Indeed, such phenomena as the BBC Television programme, The White Heather Club, which ran from 1958 
to 1968, may stand as emblem for more recent versions of Lauderism and tartanry that have been easy to excoriate, but have served more positive functions than a middle-class establishment has always been ready to allow. The BBC's own Website, in referring to this programme as a key product of its period, observes in a queasy self-commentary:

Andy Stewart presented and sang in the Scottish country dance music show which, at its peak, drew in an audience of 10 million and turned Stewart into an international star. This very Scottish image, awash with kilts and fiddles, is one which the rest of the network took to be a true representation of Scotland ${ }^{18}$ !

The exclamation mark speaks for the unease of the modern commentator faced with the sentimentality of The White Heather Club. Yet, it is truly doubtful that anyone in their right mind could have taken the tartanised sentimental faux-jollity of The White Heather Club as a «true» and full representation of Scottish life in all its complexity and richness in age when, for example, both coal and ship-building industries were in full swing. Indeed part of the problem with such a misperception is that is assumes that there is in fact such a thing as a «true representation» of Scotland. Even significant critics have fallen into such an essentialist trap. John Caughie has observed:

the memory of The White Heather Club lingers on as if it were only yesterday $[. .$.$] and although Hogmanay specials only happen once$ a year it takes at least twelve months to forget them. As well as being almost fascinating in their awfulness, such programmes have a particular regressive potency precisely because they slot into the recognisable discourses so smoothly. However infrequent they may be, they have a certain defining power, confirming and reinforcing the image of the «essentially Scottish». (McArthur, p. 120)

It is certainly not hard to agree with Murray Pittock's description of the process that led to 1980s Hogmanay programming as a degringolade, a sharp decline, but that is a matter of critical taste about a particular form of programming and performance. Such a view is entirely understandable and many reading this article would agree with it. Such a judgement of taste should,

18. Information at <http://www.bbc.co.uk/ scotland/aboutus/wireles stoweb $>$ however, not be confused with arguments such as Caughie presents about conceptions of essential Scottishness, a doubtful concept in any case, requiring severe interrogation. 
It is equally questionable that Harry Lauder, a contemporary of, to name but three, Andrew Carnegie, Sir Alexander Fleming and Hugh MacDiarmid himself, could be seen as, on his own, the archetypal Scot. What both Lauder and, later, The White Heather Club with Andy Stewart do is sustain a specific strand within a varied Scottish culture. This strand, like it or not, incorporates popular and music hall traditions which are at times trivial and fatuous in ways that infuriate such intellectuals as Hugh MacDiarmid, but are nonetheless Scottish for that. And this strand is part of range of means by which Scots maintained their cultural identity and self-awareness in the context of what Craig, quoting Graeme Morton, calls unionist nationalism. Such devices, however, while arising in a context in which unionist nationalism is important in maintaining a Scottish identity within a separate but equal political union, are not restricted to that function. They also serve a sense of identity that may work against, as much as for, unionism. However Lauder's version of tartanised Scottishness arose within a unionist context, tartanry itself serves the sense of Scottish identity first and foremost, not that of unionism. It sustains one of the wide range of Scottish identities that may as easily find a new expression outside the Union as within.

Anyone who watches the exaggerations of Lauder and The White Heather Club will recognise two further factors. One is that, within the dramaturgic context of music hall and variety where most «turns» lasted around four to seven minutes and had far fewer to establish an impact, caricature was a crucial theatrical convention, whether provided by Scotch Comedians or Cockney Singers like Marie Lloyd. The second is that an ironic and self-caricaturing function is served by such performances, not unlike, in a similar politico-imperial context, that of the Good Soldier Schweyk. Indeed, the campness of the costumes of Lauder or The White Heather Club dancers, singers and dancing serves for the informed observer precisely the subversive function of Camp mentioned earlier. There is knowingness about Andy Stewart's version of Scottishness that challenges its being taken at face value. Certainly, the tendency to sentimentality often works against the material being presented. Lauder's «Keep right on to the end of the road» is often seen as a sentimental song about homecoming when it is more appropriately read as a counsel against despair, and even suicide, written by a widower whose only - and childless - son 
has been killed in war. Stewarts'Scottish Soldier is undoubtedly a paean at one level to Scottish militarism. Nonetheless, its braggart patriotism is asserted through flaccid rhymes «soldier... none bolder»-that undermine the very braggadocio being asserted.

It is not the purpose of this paper to assert that all was admirable about the phenomenon of tartanry or the sentiments of the Scottish music hall. Rather it seeks to assert that they embody far more complex realities than more condemnatory critics have allowed. It is arguable that those critics have responded to a surface and simplistic reading of a phenomenon that has greater complexity, richness and importance for the sustenance of the varieties of Scottish identity than their arguments appear to grasp. A full critique of Lauder cannot be found in the polemic and politically committed stances of MacDiarmid or of tartanry in those of Grigor and McArthur. It is not possible here, either, to attempt a detailed critique of Lauder's performances, but the merest review of the iconography of his costumes will establish his use of tartanry as an identifier of a version of Scottish culture. And the varieties of Scottish culture remain important differentiators in the context of the dangers of globalisation. As John McGrath has observed of the value of diversity:

Diversity in nature, in human experience, in the language of living, in peoples, is one of the great sources of joy. A culture that is loved, guarded, and developed will tend to have more subtlety, more specific reference, more density than a demotic that has to serve the needs of half the world ${ }^{19}$.

Even the commercialised version of Scottishness embodied in Lauder's music hall and The White Heather Club serves in conjunction with other expressions of Scottish identity, including the poetry and prose of MacDiarmid, the function of asserting diversity.

It remains true, however, that contemporary Scots in Scotland often feel unease at such versions of their culture. Such unease may be found in current critical discourse. The drama

19. John McGrath, «Scotland: the Writing on the Wall»,

The Weekend Guardian, 1-2 April, 1989, p. 2-3 (Holdsworth, p. 189). critic, Joyce McMillan, for example, faced with W.S. Gilbert's ironic use of the stereotypical Stage Scotsman of melodrama, observes in a review of Gilbert's Engaged at Pitlochry Festival Theatre: 
The play opens in a kitsch Victorian version of Scotland, where the wily locals have taken to derailing trains so that they can turn a honest penny by offering shelter and refreshments to the travelling gentry; whether modern Scots are supposed to find this casual slap of metropolitan attention flattering or enraging is hard to say, but it's certainly formidably silly ${ }^{20}$.

Clearly, in this context, McMillan might have allowed more tolerance to a theatrical convention that is now nearly a century and half old, relating to another time and now presented on stage as a historical phenomenon. Yet, her unease reflects something of the general unease of contemporary Scots faced with such a phenomenon. The Stage Irishman of the melodrama is now easily tolerated, even celebrated, as in various revivals over the last two decades, at the Royal National Theatre, Edinburgh's Royal Lyceum Theatre and the Abbey Theatre, of Boucicault's classic melodrama, The Shaughran. It may be that the Irish stereotype is more acceptable because of the different political status of Ireland in the modern age. It would certainly be a sign of growing maturity and historical understanding if the Victorian theatre's Stage Scotsman were equally well understood and accepted as the product of specific historical conditions ${ }^{21}$. It is a double irony that WS Gilbert's satire on a melodramatic convention should be taken at face value and so criticised in a modern review.

Scottish culture in any case is not just for Scotland. The market offered by diaspora Scots, for example, sustained the careers of earlier icons like Frame and, especially, Lauder. Yet, while Scottish culture is mother culture for the diaspora, the diaspora preserves its own versions of that Scottish culture that it holds in high regard, however they are perceived at home. In Wagram, North Carolina, for example, on the morning of Saturday, 6 September 2002, the author was witness to the following ceremonial events. The sound of bagpipes was to be heard as police stopped the traffic on that small town's main street. Along came a kilted pipe band playing Scotland the Brave and on the main crossroads of the town the procession halted.

20. The Scotsman, 5 May 2004.

21. For further

discussion of the actual and ironic use of such conventions of

melodrama, see, for instance (Meisel, 1963). A group of young people toward the front of the procession in Highland dress Highland danced on that crossing. The procession then proceeded with fire engines and other civic vehicles representing the whole local community. The band members and dancers clearly included a majority of Hispanic Americans and Lumbee Indians - probable descendants of 
Native Americans'intermarrying with Walter Raleigh's abandoned Roanoke Island settlers. This was their culture as much as anyone's. Their version of Scottishness had become appropriated and appropriate to their needs and their diaspora Scottish cultural identity - even to the extent that it included those who had adopted a diaspora Scots identity in the Scottish dominated areas of North Carolina. It is possible for home Scots to regard such activity and the many Highland Games of North America and Australia as sentimental and oldfashioned. Yet, they clearly celebrate something that is the Scottish diaspora's - and another strand of Scottishness. Indeed it is hard to argue that what was seen at Wagram - or in the more famous manifestations of Tartan Day, established as recently as 1998 - is in fact old-fashioned. However based on historic forms, it is a public re-fashioning of another aspect of Scottish identity. It is as much a part of the world culture that is Scottish as the work of the most cutting-edge home-based modern artists and critics. One thing that a study of the history of popular theatre, of the music hall and Harry Lauder, teaches us is that there are those, often self-appointed and even seeming unco guid, who would narrow the definition of Scottish culture by the use of their own manufactured shibboleths. Another thing such a study teaches is that Scottish culture is a large, dynamic and international mansion with many houses filled by many varieties of «authenticity» and «truth» to such an extent that these terms may serve little valuable function ${ }^{22}$.

22. In researching and drafting this paper, I am, as ever, indebted to Dr Bill Findlay for his generous advice and assistance.

\section{Bibliography}

Cameron A. and Scullion A. eds., Scottish Popular Theatre and Entertainment, Glasgow, Glasgow University Library, 1996.

DiCenzo M., The Politics of Alternative Theatre in Britain, Cambridge, Cambridge University Press, 1996.

Findlay B. ed., A History of Scottish Theatre, Edinburgh, Edinburgh University Press, 1998.

Holdsworth N. ed., Naked thoughts that roam about, London, Nick Hern Books, 2002.

Lucas I., Impertinent Decorum, London, Cassell, 1994.

McArthur C. ed., Scotch Reels: Scotland in Cinema and Television, London, British Film Institute, 1982. 
MacDiarmid H., Lucky Poet: A Self-Study in Literature and Political Ideas, London, Methuen, 1943,

-, Complete Poems 1920-1976, vol. 1, M. Grieve and W.R. Aitken eds., London, Martin Brian \& O'Keeffe, 1978.

-, The Raucle Tongue: Hitherto uncollected prose, vol II, A. Calder, G. Murray and A. Riach eds., Manchester, Carcanet, 1997.

Maloney P., Scotland and the music hall 1850-1914, Manchester, Manchester University Press, 2003.

McCrone D., Understanding Scotland: The sociology of a stateless nation, London, Routledge, 1992.

Meisel M., Shaw and the Nineteenth-Century Theater, Princeton NJ and London, Princeton University Press, 1963.

Pittock M.G., The Myth of the Jacobite Clans, Edinburgh, Edinburgh University Press, 1995.

Schneider E.W. ed., Englishes Around the World, vol. 1, Amsterdam/Philadelphia, John Benjamins Publishing Company, 1997.

Stevenson R. and Wallace G. eds., Scottish Theatre since the Seventies, Edinburgh, Edinburgh University Press, 1996. 